\title{
Gudstjenester i skoletiden - behov for en klarere rollefordeling mellom kirke og skole?
}

\author{
Av OLAV HoVDELIEN, professor ved OsloMet, e-post: Olav.Hovdelien@oslomet.no, \\ og GUNNAR NEEGAARD, dosent em. OsloMet, e-post:gunnarne@oslomet.no.
}

Det kommer jevnlig opp diskusjoner i offentligheten om tradisjonen med skolegudstjenester bør videreføres i dagens samfunn, et samfunn som i økende grad preges av sekularisering og religiøs diversitet. Det er også en tydelig interesse blant forskere for problemstillinger knyttet til å arrangere slike gudstjenester (jf. Øverlien og Kjørven, 2019; Øierud, 2019; Løvland og Repstad, 2019; Bråten, 2019). I 2014 publiserte vi resultatene fra en empirisk undersøkelse rettet inn mot et utvalg skolegudstjenester som ble holdt i adventstiden i Oslo og Drammen (Hovdelien og Neegaard, 2014b). Vi skrev også en artikkel der vi drøftet nærmere hva som står på spill når skolen og kirken går sammen om å arrangere gudstjenester med forventet elevdeltakelse i skoletiden. Her presenterte vi noen «kjøreregler» som vi mener bør ligge til grunn i forbindelse med arrangering av slike gudstjenester (Hovdelien og Neegaard, 2014a). Siden den gang har diskusjonene om slike gudstjenester fortsatt. Spørsmålet har også vært behandlet av Stortinget, og i november 2019 publiserte Utdanningsdirektoratet en ny nasjonal veileder der skolene blir «oppfordret til å legge til rette for at elevene skal kunne delta på skolegudstjenester» (Utdanningsdirektoratet, 2019; Dokument 8:63 S (2017-2018); Innst. 192 S. (2017-2018)).

Utdanningsdirektoratet viser $\mathrm{i}$ veilederen til at det er «tradisjon for å la elevene delta på gudstjeneste i skoletiden», men at foreldrene må få informasjon i god tid «hvis skolen ønsker å tilby elevene å delta på skolegudstjeneste.» (Utdanningsdirektoratet, 2019).

På bakgrunn av stortingsbehandlingen og innholdet $\mathrm{i}$ veilederen fra Utdanningsdirektoratet har vi behov for å presisere det vi anser som sentrale anliggender $\mathrm{i}$ forbindelse med håndteringen av gudstjenester i skoletiden. Vi er blitt styrket i oppfatningen av at nøkkelen til en god praksis i forbindelse med slike gudstjenester ligger i en klar og tydelig rollefordeling mellom kirken på den ene siden, og skolen på den andre. Vi håper derfor at denne refleksjonsartikkelen kan være et bidrag til å dempe konfliktnivået og gjøre det enklere for skolen og kirken å samhandle i slike saker, ut fra en grunnforståelse av at det er snakk om to ulike samfunnsinstitusjoner som har hver sin integritet å bevare. I tillegg er det naturligvis alltid viktig å minne om den menneskerettsforankrede foreldreretten, som må få avgjørende betydning i denne typen spørsmål. Vi tror også at en tydelig bevissthet om foreldrenes og de foresattes rettigheter vil giøre det enklere å se det 
prinsipielle ved rollefordelingen mellom skole og kirke. Normalt sett er det også foreldrene og de foresatte som er best i stand til å ta vare på hensynet til elevenes beste.

\section{ER DET SKOLEN ELLER KIRKEN SOM HOLDER GUDSTJENESTER?}

I Utdanningsdirektoratets veileder er skolene «oppfordret til å legge til rette for at elevene skal kunne delta på skolegudstjenester i forbindelse med høytider» (Utdanningsdirektoratet, 2019). Det betyr at direktoratet gir skolen myndighet til å avgjøre om det blir noen gudstjeneste eller ikke. At kirken ikke er tildelt noen rolle i saken, kan tyde på at man bevisst styrer unna vanskelige prinsipielle avveininger. Dersom vi stilte direktoratet spørsmål om religionsutøvelse og forkynnelse i skolens fag er en del av «skolens virksomhet», vil svaret naturligvis være «nei». Direktoratet vil naturligvis også svare «nei» på spørsmålet om det er tillatt å arrangere gudstjeneste for elevene på skolen. Direktoratet vil sannsynligvis si at en slik løsning heller ikke er en del av «skolens virksomhet».

Situasjonen stiller seg derimot annerledes når elevene forflytter seg fra skolen til kirken. Da ligger det nær å anta at direktoratet mener at det er en del av «skolens virksomhet» å gi elevene adgang til å delta på gudstjeneste i kirken. Mener direktoratet at problemet er løst bare man bytter arena?

Vi er ganske sikre på at denne selvmotsigelsen ikke vil stå seg hvis det kommer krav om en prinsipiell avklaring. Det kan ikke forsvares prinsipielt at all religionsutøvelse som skjer i skoletiden, er å anse som en del av skolens virksomhet. Kirken kan som selvstendig samfunnsinstitusjon holde gudstjenester for hvem som helst, også for skoleelever i skolens åpningstid. Når kirken holder gudstjeneste for skolens elever, har den en rolle i saken. Vi mener det er nødvendig å avklare hva den innebærer.

\section{LANG TRADISJON FOR GODT SAMARBEID MELLOM KIRKE OG SKOLE}

Det er lang tradisjon for et nært og godt samarbeid mellom kirke og skole. Vi mener at dette samarbeidet bør videreføres, forutsatt at rollefordelingen klargjøres. Som nevnt over, heter det i Utdanningsdirektoratets nasjonale veileder at det er «tradisjon for å la elever delta på gudstjeneste i skoletiden i forbindelse med høytider», og at «skolene er oppfordret til å legge til rette for at elevene skal kunne delta ...» (Utdanningsdirektoratet, 2019).

I den nasjonale veilederen knyttes tradisjonen til skolens overordnede verdier og prinsipper for opplæringen, der det blant annet står at skolen «skal gi elevene historisk og kulturell innsikt og forankring, og bidra til at hver elev kan ivareta og utvikle sin identitet $i$ et inkluderende og mangfoldig fellesskap» 
(Utdanningsdirektoratet, 2019). Å delta på gudstjeneste eller andre høytidsmarkeringer antas å være en del av denne tradisjonen. Opplæringsloven er fortsatt tydelig på at forkynnelse ikke er tillatt i KRLE-undervisningen. Siden gudstjenester per definisjon innebærer religionsutøvelse, kan praksisen med skolegudstjenester ikke knyttes til dette faget og dets læringsinnhold (jf. opplæringsloven §2-4).

Videre presiserer veilederen at skolegudstjenester ikke bør være en skoleavslutning, fordi skoleavslutningen skal være inkluderende og foregå slik at alle elever kan delta. Veilederen understreker derfor at «... skoler som tilbyr elevene å delta på en skolegudstjeneste, må også tilby et likeverdig alternativ for elever som ikke ønsker å delta på gudstjenesten. Dette skal være noe annet enn en gudstjeneste, men det alternative tilbudet skal også være et pedagogisk opplegg, der elevene lærer om kultur og tradisjoner i Norge. Det skal være et planlagt tilbud, og skolen skal gi god informasjon til elever og foreldre om hva det alternative tilbudet er».

Vi mener at direktoratet her gir riktige og prinsipielt viktige beskrivelser av det alternative tilbudet.

\section{AKtiv PÅmelding Sikrer Foreldreretten}

Foreldresamarbeidet er prinsipielt sett det sentrale punktet $\mathrm{i}$ den nasjonale veilederen.

Et aktivt foreldresamarbeid er en forutsetning for at skolegudstjenester skal kunne arrangeres. I veilederen heter det derfor: «Skolen bør involvere foreldrene i dialog om deltakelse i og gjennomføring av skolegudstjenester, og hva som kan være et alternativt tilbud ... Skolen skal gi informasjon til alle foreldre i god tid hvis skolen ønsker å tilby elevene å delta på skolegudstjeneste. Samtidig skal skolen gi informasjon om det alternative tilbudet til elevene som ikke ønsker å delta på gudstjeneste.» (Utdanningsdirektoratet, 2019).

Etter vår mening ivaretar vi foreldreretten best ved å innføre en ordning med påmelding, der foreldrene eller andre foresatte aktivt gir beskjed om at deres barn skal delta på skolegudstjenester. Da vil også behovet for fritak falle bort, fordi de elevene som ikke er påmeldt, ikke deltar. Aktiv påmelding kan også administreres på andre måter, f.eks. ved at foreldrene får spørsmål om deltakelse når barna begynner på skolen. Slik kan skolen gi et tydelig signal om at den respekterer foreldrenes standpunkt, samtidig som foreldrene slipper bryet med påmeldinger fra gang til gang.

\section{SKOLEN OG KIRKEN HAR ULIKE ROLLER}

Når det gjelder skolens rolle i forbindelse med skolegudstjenester, er ordlyden $\mathrm{i}$ Utdanningsdirektoratets veileder ikke til å misforstå. Spørsmålet om deltakelse i skolegudstjeneste er alene skolens ansvarsområde. Skolen skal riktignok involvere foreldrene i avgjørelsen, men det er skolen som avgjør om det blir noen gudstje- 
neste. Direktoratet formulerer det slik: «... hvis skolen ønsker å tilby elevene å delta på skolegudstjeneste».

Etter vårt syn er veilederen uryddig på dette punktet, da det er kirken som holder gudstjenester, ikke skolen. Derfor er det forbausende at veilederen ikke sier noe om kirken og dens rolle. Også i et historisk perspektiv er dette spesielt, da skolen er et "produkt» av reformasjon, opplysningstid og kirkelig konfirmasjon. Når direktoratet henviser til hva det er «tradisjon for», mener vi det er naturlig å forslå en endring. Vi mener at invitasjon til skolegudstjeneste bør komme fra kirken. Bare slik får kirken den rollen den fortjener. Invitasjonen bør gå til rektor som tar den videre til foreldrene/ foresatte. Det er som nevnt, foreldrene som har det overordnede oppdragermandatet.

\section{NøDVENDig MED AVKLARING AV ROLLEFORDELINGEN MELLOM SKOLEN OG KIRKEN}

Vi mener altså at det er helt nødvendig å foreta en rollefordeling mellom kirke og skole i denne saken. Kirken representerer en religion. Det gjør ikke skolen. På prinsipielt grunnlag vil vi derfor slutte oss til oppfatningen av at religionsutøvelse ikke er en del av skolens virksomhet, enten den skjer i skolen eller i skolens regi. Men å administrere en invitasjon fra kirken der foreldrene besvarer invitasjonen med å melde barna på skolegudstjeneste, er noe annet.

En slik klargjort rollefordeling mellom kirke og skole har flere fordeler. Anklagene om at skolen driver religionsutøvelse bortfaller, fordi det er foreldrene som avgjør, ikke skolen og dens organer. Fordi det er foreldreretten som gjelder, er det heller ikke noe grunnlag for konfliktfylte diskusjoner på skolene. Skolens rolle bør begrense seg til å administrere deltakelse i gudstjeneste, og ved å legge forholdene til rette for et likeverdig alternativt pedagogisk opplegg på skolen.

\section{Deltakelse PÅ SKolegudstjenester MÅ VÆRE FRIVillig}

Det er flere fordeler knyttet til denne grenseoppgangen mellom kirkens og skolens domener. Å holde gudstjeneste er kirkelig virksomhet. Og når man går i kirken til gudstjeneste, betyr det normalt at man deltar i religionsutøvelse (jf. Øierud, 2019). Deltakelse i kirkens gudstjeneste er frivillig, enten man er voksen eller barn. Det kan ikke være annerledes når kirken inviterer skolens elever til gudstjeneste. Skolen har regler om fritak, det har ikke kirken. Av den rollefordelingen vi har tatt til orde for ovenfor, følger at det også må være tydelig at det er kirken som har regien i slike gudstjenester. Det er naturligvis ikke til hinder for aktiv medvirkning fra skolens og elevenes side, i samarbeid med kirken. Kirken må uansett tilpasse sin gudstjenesteordning til barn i ulike aldre (jf. Løvland og Repstad 2019).

Ut fra gitte betingelser og en klar rollefordeling mellom skolen og kirken, og med et aktivt foreldresamarbeid, mener vi at tradisjonen med skolegudstjenester bør videreføres, enten de foregår i forbindelse med jul, påske eller 17. mai. 


\section{LitTERATUR}

Bråten, Oddrun Marie Hovde. 2019: «Mye på spill: Den nasjonale debatten om skolegudstjenester belyst med to lokale caser», Din. Tidsskrift for Religion og kultur nr. 2 http://ojs.novus.no/index.php/DIN/article/view/1720/1702 (lastet ned 14.1.2020)

Dokument 8:63 S (2017-2018) Representantforslag 63 S (2017-2018), https://www.stortinget.no/no/Saker-og-publikasjoner/Publikasjoner/ Representantforslag/2017-2018/dok8-201718-063s/?all=true (lastet ned 18.12.2019)

Hovdelien, Olav og Gunnar Neegaard. 2014a: «Gudstjenester i skoletiden», Bedre skole nr. 2 (s. 58-63).

Hovdelien, Olav og Gunnar Neegaard. 2014b: «Gudstjenester i skoletiden rektorenes dilemma», Norsk Pedagogisk Tidsskrift. Årgang 98 nr 4 (s. 260-270).

Innst. 192 S. (2017-2018) Innstilling fra utdannings- og forskningskomiteen om Representantforslag fra stortingsrepresentantene Hans Fredrik Grøvan, Olaug V. Bollestad, Steinar Reiten og Kjell Ingolf Ropstad om å gi alle elever i Norge tilbud om skolegudstjeneste før jul

Lov om grunnskolen og den vidaregåande opplæringa (opplæringslova), https:// lovdata.no/dokument/NL/lov/1998-07-17-61 (lastet ned 24.11.2019).

Løvland, Anne og Pål Repstad. 2019: «Mellom forkynning, kulturarv og inkludering. Skulegudstenester før jul.», i Kirke og kultur, årgang 2019 nr. 3. (s. 207-223).

NOU 2013:1 Det livssynsåpne samfunn, https://www.regjeringen.no/no/ dokumenter/nou-2013-1/id711212/ (lastet ned 24.11.2019).

Forsknings- og Utdanningskomiteen 2018. Skolegudstjenester, Dokument 8:63 S (2017-2018) https://www.stortinget.no/no/Saker-og-publikasjoner/ Publikasjoner/Representantforslag/2017-2018/dok8-201718-063s/ (lastet ned 24.11.2019).

Utdanningsdirektoratet. 2015. «Gudstjenester i skoletiden.» Tolkningsuttalelse vedrørende skolegudstjenester. https://www.udir.no/regelverk-og-tilsyn/ finn-regelverk/etter-tema/Innhold-i-opplaringen/Gudstjenester-i-skoletiden

Utdanningsdirektoratet. 2019. «Skolegudstjenester», sist endret 25.02.2019. https://www.udir.no/regelverk-og-tilsyn/skole-og-opplaring/saksbehandling/skolegudstjenester/ (lastet ned 24.11.2019)

Øierud, Gunnfrid Ljones. 2019. «Skolegudstjenester. Føringer, friksjon, forandring», i Prismet, årgang 2019 nr. 3 (s. 257-281).

Øverlien, Mina og Ole Kolbjørn Kjørven. 2019. «Juleavslutninger i skolen - et inkluderende fellesarrangement?», i Prismet, årgang 2019 nr. 4 (s. 343-360). 